\title{
UPAYA PENINGKATAN PENALARAN MATEMATIS MAHASISWA UNIVERSITAS TRIBHUWANA TUNGGADEWI MELALUI PENDEKATAN CONTEXTUAL TEACHING AND LEARNING (CTL)
}

\author{
Rio Febrianto Arifendi ${ }^{1}$, Rudy Setiawan ${ }^{2}$ \\ 1,2 Universitas Tribhuwana Tunggadewi \\ rioarifendi@gmail.com
}

\begin{abstract}
Abstrak
Penelitian ini bertujuan mendeskripsikan langkah-langkah pembelajaran dengan menggunakan pendekatan Contextual Teaching Learning (CTL) yang dapat meningkatkan penalaran matematis mahasiswa, sehingga masalah penalaran matematis mahasiswa teratasi dengan baik dalam proses pembelajaran, Rancangan dalam penelitian ini merupakan menggunakan pendekatan kualitatif dengan jenis penelitian tindakan kelas (Classroom Action Research). Rancangan penelitiannya terdiri dari beberapa tindakan, satu tindakan dinamakan siklus. Kegiatan setiap siklus terdiri dari empat kegiatan pokok, yaitu perencanaan (planning), tindakan pelaksanaan (action), observasi (observation), dan refleksi (reflection). Strategi CTL yang digunakan dalam penelitian ini memuat: Relating, Cooperating, Experiencing, Appliying, Transfering. Hasil penelitian menunjukkan bahwa: (1) Implementasi pembelajaran dengan pendekatan CTL terdiri dari: Mahasiswa mengamati permasalahan, menuliskan permasalahan, menyelesaikan permasalahan, dan mahasiswa mendiskusikan permasalahan; (2) Penalaran matematis mahasiswa yang belajar dengan menggunakan CTL mengalami peningkatan; (3) Pembelajaran dengan CTL disukai mahasiswa.
\end{abstract}

Kata kunci: CTL, penalaran matematis

\begin{abstract}
This study aims to describe the learning steps by using the Contextual Teaching Learning (CTL) approach that can improve students 'mathematical reasoning, so that students' mathematical reasoning problems are well resolved in the learning process. Classroom Action Research). The research design consists of several actions, one action is called a cycle. The activities of each cycle consist of four main activities, namely planning (planning), action (action), observation (observation), and reflection (reflection). The CTL strategy used in this study includes: Relating, Cooperating, Experiencing, Appliying, Transfering. The results of the study show that: (1) Implementation of learning with an CTL approach consists of: Students observe problems, write problems, solve problems, and students discuss problems; (2) Mathematical reasoning of students who study using CTL has increased; (3) Learning with CTL is favored by students.
\end{abstract}

Key words: CTL, mathematical reasoning 
Arifendi, Rio Febrianto \& Setiawan, Rudy

Upaya Peningkatan Penalaran Matematis Mahasiswa Universitas Tribhuwana Tunggadewi Melalui

Pendekatan Contextual Teaching and Learning (CTL)

\section{PENDAHULUAN}

Permenristekdikti No 44 tahun 2015 menyebutkan standar kompetensi lulusan kurikulum perguruan tinggi sebagai sasaran pembelajaran di setiap satuan pendidikan mencakup pengembangan tiga ranah kompetensi. Salah satu dari ketiga ranah tersebut adalah keterampilan. Keterampilan diperoleh melalui salah satu aktivitas yaitu menalar dan menjadi kompetensi inti dalam perguruan tinggi. Demikian juga dalam pembelajaran matematika, kegiatan menalar dikembangkan di tingkat pendidikan strata 1 (S1). Hal tersebut menunjukkan bahwa kemampuan penalaran matematis menjadi salah satu komponen yang sangat penting dalam pemebelajaran matematika.

NCTM (2000: 56) menyatakan bahwa kemampuan bernalar akan membuat seseorang mengetahui mengapa harus belajar matematika. Kegiatan menalar seperti mengembangkan ide, mengeksplorasi fenomena, memberikan alasan atas suatu jawaban, dan membuat dugaan matematis sangat penting dalam memahami matematika. Oleh karena itu, penalaran matematis perlu dikembangkan secara konsisten di berbagai konteks. Ball \& Bass dalam Brodie (2010) menjelaskan bahwa penalaran penting untuk pemahaman konsep matematika, penggunaan ide-ide dan prosedur matematika secara fleksibel, dan merekonstruksi pemahaman. Materi matematika dapat dipahami melalui penalaran, sebaliknya penalaran dapat dipahami dan dilatihkan melalui belajar matematika. Namun, penalaran matematis yang dimiliki oleh mahasiswa di Indonesia saat ini belum sesuai harapan. Hal ini didukung dengan data dari Trend in International Mathematics and Science Study (TIMSS) pada tahun 2015. Hasil TIMSS dari Puspendik (2015) menunjukkan bahwa skor Indonesia pada bidang penalaran mateatika pada tahun tersebut hanya 20 dari skor rata-rata internasional yang mencapai 44 . Hal ini mengindikasikan bahwa penalaran matematis siswa di Indonesia masih rendah.

Hal di atas juga dialami oleh mahasiswa kelas A Teknik Sipil Universitas Tribhuwana Tunggadewi bahwa penalaran matematis masih rendah. Berdasarkan data nilai akhir mata kuliah Matematika, tercatat bahwa 21 dari 29 mahasiswa di kelas tersebut tidak mencapai nilai $\mathrm{B}$ atau skor minimal 70 .

\section{METODE PENELITIAN}

Penelitian ini menggunakan pendekatan kualitatif dengan jenis penelitian tindakan kelas (Classroom Action Research). Pemilihan jenis penelitian ini didasarkan pada alasan 
permasalahan penelitian yaitu untuk memperbaiki pembelajaran di kelas kelas A Teknik Sipil Universitas Tribhuwana Tunggadewi mata kuliah Matematika. Data yang diperoleh akan dianalisis secara kualitatif deskriptif dan kuantitatif yang memaparkan penerapan Contextual Teaching and Learning (CTL) untuk meningkatkan penalaran matematis mahasiswa di kelas tersebut. Pada rancangan penelitian, satu tindakan dinamakan siklus. Kegiatan setiap siklus terdiri dari empat kegiatan pokok, yaitu perencanaan (planning), tindakan pelaksanaan (action), observasi (observation), dan refleksi (reflection). Apabila tindakan pada siklus pertama tidak berhasil, maka dilakukan tindakan untuk siklus berikutnya. Rancangan penelitian ini mengacu model yang dikembangkan 0'Leary (2004).

\section{HASIL DAN PEMBAHASAN}

Pada bagian ini beberapa hal yang akan dibahas yaitu langkahlangkah pembelajaran yang dapat meningkatkan penalaran matematis mahasiswa dan tes penalaran matematis mahasiswa.

Langkah-langkah Pembelajaran Yang Dapat Meningkatkan Penalaran Matematis

\section{Mahasiswa}

Pembelajaran yang dapat meningkatkan pemahaman mahasiswa selama penelitian meliputi tiga kegiatan, yaitu kegiatan awal, terdiri dari mengingatkan materi sebelumnya, menjelaskan materi pokok dan indikator yang akan dicapai pada pembelajaran dan memberikan motivasi kepada mahasiswa, kegiatan inti yang terdiri dari: (a) Mahasiswa mengamati permasalahan. Pada tahap ini mahasiswa mendapatkan Worksheet dari dosen mengenai materi yang diajarkan pada pertemuan tersebut. Worksheet yang dibagikan dalam bentuk masalah yang harus diselesaikan oleh mahasiswa secara berkelompok. Gambaran masalah tersebut merupakan materi yang mereka pelajari pada pertemuan tersebut. Mahasiswa ditunjukkan mengenai materi peluang. (b) Mahasiswa menuliskan permasalahan. Pada kegiatan ini mahasiswa diminta untuk mengajukan permasalahan secara tertulis pada lembar yang disediakan oleh peneliti. Mahasiswa menuliskan permasalahan sesuai dengan materi yang sedang mereka pelajari pada pertemuan tersebut. Soal yang ditulis nantinya akan dicari penyelesaiannya. Hal tersebut merupakan langkah awal bagi mahasiswa untuk memahami materi peluang yang sedang dipelajari. (c) Mahasiswa menyelesaikan permasalahan, Pada siklus I, kegiatan ini 
Arifendi, Rio Febrianto \& Setiawan, Rudy

Upaya Peningkatan Penalaran Matematis Mahasiswa Universitas Tribhuwana Tunggadewi Melalui

Pendekatan Contextual Teaching and Learning (CTL)

mahasiswa secara berkelompok mengerjakan soal yang mereka susun pada tahap sebelumnya. Namun pada siklus II, tahap menyelesaikan permasalahan dilakukan dengan mekanisme kelompok penyusun soal tidak boleh mengerjakan soal yang mereka susun. Akan tetapi soal dikerjakan oleh kelompok lain yang tidak ikut menyusun soal tersebut. Perbedaan tindakan pada kedua siklus tersebut merupakan upaya perbaikan yang dilakukan peneliti. (d) Mahasiswa mendiskusikan permasalahan, Pada tahap ini mahasiswa diminta untuk menampilkan soal yang telah disusun beserta penyelesaiannya secara klasikal. Kegiatan ini berperan dalam membentuk pemahaman mahasiswa secara klasikal. Sesuai dengan pernyataan Anthony (2009), bahwa diskusi dapat membantu mahasiswa untuk belajar dari kesalahan atau kesulitan yang dipelajari.

Berdasarkan hasil tes penalaran matematis mahasiswa yang dilakukan pada dua siklus, ketuntasan klasikalnya adalah $76,46 \%$ pada siklus I serta $81,77 \%$ pada siklus 2 . Hal ini berarti terjadi peningkatan terhadap penalaran matematis mahasiswa dari siklus I ke siklus II.

\section{KESIMPULAN DAN SARAN}

Berdasakan hasil dan pembahasan dapat disimpulkan bahwa penerapan pembelajaran Contextual Teaching and Learning (CTL) yang dapat meningkatkan penalaran matematis mahasiswa, sehingga masalah penalaran matematis mahasiswa teratasi dengan baik dalam proses pembelajaran.

\section{DAFTAR PUSTAKA}

Bergqvist, et.al. 2006. Upper Secondary Students' Task Reasoning. International Journal of Mathematics Education in Science and Technology, 29(1): 1-9.

Brodie, K. 2010. Teaching Mathematical Reasoning in Secondary School Classroom. New York: Springer.

Crawford, M.L. 2001. Teaching Contextually: Research, Rationale, and Techniques for Improving Student Motivation and Achievement in Mathematics and Sciene. Texas: CORD Communications, Inc.

Mullis, I. et al. 2012. TIMSS 2011 International Results in Mathematics. Chestnut Hill, USA: TIMSS \& PIRLS International Study Center.

NCTM. 2009. Focus in High School Mathematics: Reasoning and Sense Making. Reston, VA: The National Council of Teachers of Mathematics, Inc.

Nickerson, R.S. 2010. Mathematical Reasoning: Patterns, Problems, Conjectures, and 
Proofs. New York: Psychology Press.

O'Leary, Z. 2004. The Essential Guide to Doing Research. London: SAGE Publication.

Permenristekdikti No. 44 Tahun 2015. Tersedia Online: (http://www.kopertis12.or. id/2016/01/15/permenrist ekdikti-no-44-tahun-2015tentang-standar-nasionalpendidikan-tinggi), diakses 12April 2017.

Parta, I Nengah. 2009. Pengembangan Model Pembelajaran Inquiry untuk Penghalusan Pengetahuan Matematika Mahasiswa Calon Dosen Melalui Pengajuan Pertanyaan. Disertasi tidak diterbitkan. Surabaya: PPs UNESA.

Puspendik. 2015. Mengenai TIMSS. (Online), https://puspendik.kemdikb ud.go.id/seminar/upload/H asil\%20Seminar\%20Puspe ndik\%202016/TIMSS\%20i nfographic.pdf.

Shadiq, F. 2004. Pemecahan Masalah, Penalaran, dan Komunikasi. Disampaikan pada Diklat Instruktur/Pengembang Matematika SMA Jenjang Dasar, PPPG Matematika, Yogyakarta, 6-19 Agustus.

Tambelu, J.V.A. 2013. Development of Mathematical Learning Based Contextual in South Minahasa Regency. Journal of Education and Practice, 4(15):27-32.

Widjaja, W., Dolk, M., \& Fauzan, A. 2010. The Role of Contexts and Teacher's Questioning to Enhance Students'
Thinking. Journal of Science and Mathematics Education in Southeast Asia, 33 (2): 168-186. 